\title{
Long term outcome of very low birth weight babies born at Sri Jayawardenepura General Hospital from 1990-1995
}

\author{
Rani Wasala ${ }^{1}$. Uthpala Ranawake ${ }^{2}$ \\ Sri Lanka Journal of Child Health, 2003; 32: 92-5
}

(Key words: Long term outcome, very low birth weight babies)

\begin{abstract}
Objectives

- To compare growth parameters (weight, height, occipitofrontal circumference (OFC) and body mass index (BMI) of very low birth weight (VLBW) children with that of age and sex matched children of normal birth weight.
\end{abstract}

- To compare neurological, cognitive, educational and behavioural outcome of VLBW children with "that of control group.

Design A descriptive comparative study.

Setting Sri Jayawardenepura General Hospital (SJGH), Nugegoda.

Method VLBW babies $(<1500 \mathrm{~g})$, born at SJGH from 1990 January to 1995 December were compared with age and sex matched children of birthweights $>2500 \mathrm{~g}$. These children were 6-11 years old at time of study (September-December 2001). Of 161 survivors, 92 were assessed. Their weights, heights, OFC and BMI were noted. Wechsler Intelligence Scale for Children-Revised (WISC-R) and Draw-aman test were used to assess cognitive functions. Educational status was assessed using age appropriate reading, writing, arithmetic tests and grade 5 scholarship marks. Behavioural status was assessed using a check list.

Results Of the VLBW children, 63 (68.5\%) were preterm babies who were small for gestational age (SGA); $51(55.4 \%)$ were born to mothers with pregnancy induced hypertension $(\mathrm{PIH}) ; 46(50 \%)$ had respiratory distress; $33(35.9 \%)$ needed mechanical ventilation; 35 (38\%) had neurological disabilities.

${ }^{1}$ Consultant Paediatrician, ${ }^{2}$ Senior Registrar, Sri Jayawardenepura General Hospital, Nugegoda.

(Revised version received on 5 August 2003)
Growth parameters such as weight $(\mathrm{P}=0.000)$, height $(\mathrm{P}=0.0034)$, OFC $(\mathrm{P}=0.031)$ and $\mathrm{BMI}(\mathrm{P}=0.001)$ were significantly lower in index group compared to control group. Cognitive function, arithmetic abilities and behaviour were not significantly different in the 2 groups. However, there was a statistically significant difference in their reading and writing abilities and scholarship marks.

Conclusions The VLBW children consisted mainly of preterm babies who were SGA. PIH was the leading predisposing factor. Their catch up growth was not satisfactory and they had significant reading and writing difficulties. $38 \%$ had disabilities on neurological assessment.

\section{Introduction}

Several studies in the West ${ }^{1,2}$ have shown that very low birth weight (VLBW) children have impairment of growth, cognitive function, educational status and behaviour. Neurological abnormalities were also reported in these studies. Study done in Southampton Hospital, $\mathrm{UK}^{3}$ has shown that VLBW babies are liable to be overweight after 7 years and are prone to get cardiovascular complications at an early age. Main aim of present study was to compare long-term outcome of VLBW babies born at Sri Jayewardenepura General Hospital (SJGH), during a period of six years, in terms of their growth parameters (weight, height, occipitofrontal circumference $[\mathrm{OFC}]$, body mass index [BMI]), cognitive functions, educational status (reading, writing, arithmetic) and behavioural status with age and sex matched children of normal birth weight.

\section{Method}

Study population consisted of a cohort of VLBW $(<1500 \mathrm{~g})$ survivors born at SJGH from 1990 January to 1995 December. A normal birth weight $(>2500 \mathrm{~g})$ control population was recruited, individually matched for age and sex, from paediatric ward and clinic. Controls, taken from paediatric ward, were 
examined after allowing sufficient time for convalescence. Of 161 survivors, with whom we corresponded, 92 responded. Informed consent was obtained from parents and an intervieweradministered questionnaire was used to gather data.

A complete neurological assessment was carried out to identify motor defects, cranial nerve palsies, visual and hearing defects. We used Snellen chart, crude hearing tests, Rinne and Weber tests as tools in above assessments.

Growth assessment included measurement of weight, height and OFC. BMI was calculated using formula weight in $\mathrm{Kg} /$ (height in metres) ${ }^{2}$. Growth measurements were taken by a trained medical officer.

Cognitive function tests were assessed using Weschler Intelligence Scale for Children - Revised (WISC-R) ${ }^{4,5}$ and Good enough-Harris. Draw-a-man test $^{6}$. WISC-R consists of 6 verbal and 4 performance tests. Verbal tests were on general information, general comprehension, arithmetic reasoning, remembering series of digits forwards and backwards, similarities in pairs of words and vocabulary. Performance tests were used to assess children's ability on digit symbol coding, picture completion, block designs and picture arrangement. We had to modify test material to suit Sri Lankan children and 6 different question series were used.

Verbal and performance scores were calculated up to 100 separately so that total score was given out of 200. Perceptuomotor function was assessed by Good enough-Harris Draw-a-man test. Children were asked to draw a picture of a man. 20 characteristics of the picture were considered in giving a score. One mark was given to each criterion and a developmental quotient (DQ) ${ }^{6}$ was calculated for each child.

\section{$\mathrm{DQ}=\underline{(\text { Score } / 4)+(3 \mathrm{yrs})} \times 100$ Calendar age}

Educational status was assessed by age appropriate reading, writing and arithmetic tests based on the school curriculum for each grade. Score for reading was given out of a total score of six considering comprehensibility, making sentences and pronunciation of words.

Writing was marked out of a score of 4 whereas arithmetic tests were marked out of 8 . Before finalizing methods for educational tests, advice of the primary school teacher was sought. In addition, year five scholarship marks were noted and compared.
Behavioural assessment ${ }^{7}$ was done using a check list. The scores were given as:

$\begin{array}{lll}0 & - & \text { not true } \\ 1 & - & \text { somewhat or sometimes true } \\ 2 & - & \text { very true or often true }\end{array}$

Behaviour analysis was done in five categories:

1. Withdrawn (rather be alone, shy)

2. Anxious or depressed (cries, nervous)

3. Attention span (cannot concentrate, impulsive)

4. Aggressive behaviour (threatening)

5. Destructive behaviour

\section{Statistical Analysis}

Results were analyzed using SPSS for windows Z test was used to compare growth parameters (weight. height, OFC, BMI) and educational status. Cognitive functions, perceptuomotor function and behaviour were analysed using the Chi-square $\left(\mathrm{X}^{2}\right)$ test. $\mathrm{P}<0.05$ was considered significant. Correlation coefficient (r) between the two cognitive function tests was noted for cases and controls.

\section{Results}

Table 1 shows perinatal characteristics of the cohort of VLBW children. Table 2 lists disabilities found on neurological assessment of the children. Tables 3, 4 and 5 compare growth parameters, cognitive functions, educational status and behaviour of VLBW children with those of control group.

Table 1

Perinatal characteristics of VLBW children

\begin{tabular}{|l|c|}
\hline \multicolumn{1}{|c|}{ Perinatal Characteristic } & Value \\
\hline Birth weight 1000-1500g & $83(90.2 \%)$ \\
\hline Birth weight $<1000 \mathrm{~g}$ & $09(09.8 \%)$ \\
\hline Mean birth weight & $1270 \mathrm{~g}$ \\
\hline Mean maturity & $23(25 \%)$ \\
\hline $\begin{array}{l}\text { Preterm + appropriate for } \\
\text { gestational age }\end{array}$ & $63(68.5 \%)$ \\
\hline $\begin{array}{l}\text { Preterm + small for gestational } \\
\text { age }\end{array}$ & $06(6.5 \%)$ \\
\hline $\begin{array}{l}\text { Term + small for gestational } \\
\text { age }\end{array}$ & $46(50 \%)$ \\
\hline $\begin{array}{l}\text { Respiratory Distress } \\
\text { Syndrome }\end{array}$ & $33(35.9 \%)$ \\
\hline Number of children ventilated & $13(14.1 \%)$ \\
\hline $\begin{array}{l}\text { Culture +ve septicaemia/ } \\
\text { meningitis/NEC }\end{array}$ & $51(55.4 \%)$ \\
\hline Maternal PIH & $11(11.9 \%)$ \\
\hline Twins &
\end{tabular}


Table 2

Disabilities found on neurological assessment

\begin{tabular}{|l|c|}
\hline \multicolumn{1}{|c|}{ Disability } & No. of children \\
\hline Cerebral palsy & 06 \\
\hline Mental retardation & 03 \\
\hline Deafness & 01 \\
\hline Severe speech defect & 01 \\
\hline Autism & 01 \\
\hline Squint & 04 \\
\hline Abnormal movements & 02 \\
\hline Hearing defects & 08 \\
\hline Impaired vision & 09 \\
\hline
\end{tabular}

Table 3

Comparison of growth parameters of VLBW children and control group

\begin{tabular}{|l|l|}
\hline $\begin{array}{l}\text { Growth } \\
\text { parameter }\end{array}$ & Statistical significance \\
\hline Body weight & $\mathrm{z}=3.779 ; \mathrm{p}=0.000 ; \mathrm{S} \mathrm{df}=91$ \\
\hline Height & $\mathrm{z} 2.915 ; \mathrm{p}=0.004 ; \mathrm{S} \mathrm{df}=91$ \\
\hline OFC & $\mathrm{z}=2.185 ; \mathrm{p}=0.031 ; \mathrm{S} \mathrm{df}=91$ \\
\hline BMI & $\mathrm{z}=3.372 ; \mathrm{p}=0.001 ; \mathrm{S} \mathrm{df}=91$ \\
\hline
\end{tabular}

$\mathrm{S}=$ significant

NS - non significant

$\mathrm{df}=$ degrees of freedom

Table 4

Comparison of cognitive functions of VLBW children and control group

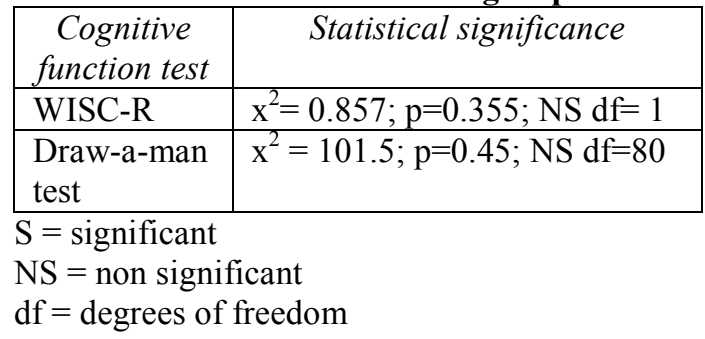

Table 5

Comparison of educational status and behaviour of VLBW children and control group

\begin{tabular}{|l|l|}
\hline $\begin{array}{l}\text { The variable } \\
\text { studied }\end{array}$ & Statistical significance \\
\hline Reading & $\mathrm{z}=4.5 ; \mathrm{p}=0.000 ; \mathrm{S} \mathrm{df}=91$ \\
\hline Writing & $\mathrm{z}=2.3 ; \mathrm{p}=0.02 ; \mathrm{S} \mathrm{df}=91$ \\
\hline Arithmetic & $\mathrm{z}=1.13 ; \mathrm{p}=0.26 ; \mathrm{NS} \mathrm{df}=91$ \\
\hline $\begin{array}{l}\text { Scholarship } \\
\text { marks }\end{array}$ & $\mathrm{z}=2.35 ; \mathrm{p}=0.026 ; \mathrm{S} \mathrm{df}=27$ \\
\hline Behaviour & $\mathrm{x}^{2}=3.9 ; \mathrm{p}=0.985 ; \mathrm{NS} \mathrm{df}=12$ \\
\hline
\end{tabular}

$\mathrm{S}=$ significant

$\mathrm{NS}=$ non significant

$\mathrm{df}=$ degrees of freedom

\section{Discussion}

$68.5 \%$ of VLBW children were preterm babies who were small for gestational age (SGA). 55.4\% were born to mothers with PIH. Growth parameters (weight, height, OFC, BMI) were significantly lower than that of control group. Neurological assessment revealed 35 (38\%) disabilities among the 92 children, WISC-R and Draw-a-man test, which were used to test cognitive functions, did not significantly differ between the 2 groups. However, educational status of VLBW children showed a statistically significant difference in reading and writing but not in arithmetic tests. Behavioural assessment, too, did not show any statistically significant difference between the 2 groups.

Inability to match a classmate to each VLBW child regarding educational variables was one of the limitations of this study. This was not feasible as our sample had children who were transferred in utero from various parts of the country. A significant number of VLBW children were lost to follow up. This was the other important limitation.

\section{Conclusions}

- VLBW children mainly consisted of preterm babies who were SGA.

- $\quad$ PIH is an important predisposing factor.

- Their catch up growth was not satisfactory.

- VLBW children had significant reading and writing difficulties.

- $\quad 38 \%$ had disabilities on neurological assessment.

\section{Acknowledgements}

We thank the children and parents who participated in our study, the staff of ward 1 and NICU at SJGH, Dr Kanchana Upasena, Dr Neelika Karunatilake, Dr Nalika Gunawardene and Dr Panduka Samarawardena for their invaluable help.

\section{References}

1. Huck M, Breslau N, Weissman B, Aram D, Klein N. Effect of very low birth weight and subnormal head size on cognitive abilities at school age. New England Journal of Medicine 1991; 325(4): 231. 
2. Fowls A. Sotting N, Cooke W I R, Pilling D, Marlow $\mathrm{N}$ Growth impairment in VLBW children at 12 years: Correlation with prenatal and outcome variables. Archives of Diseases in Childhood 1996; 75: F152-7.

3. Eriksson $\mathrm{J}$ G, Forsen $\mathrm{T}$, Tuomilinto $\mathrm{J}$, Winter $\mathrm{P}$ $\mathrm{D}$ et al. Catch up growth in childhood and death from coronary heart disease: Longitudinal study. BMJ 1999; 318: 427-31.

4. Fischer $\mathrm{M} \mathrm{A}$, Fireschein $\mathrm{O}$, editors. Intelligence, the eye, the brain, and the computer; USA; Addison-Wesley. 1987.
5. Gelder M, Gath D, Mayou R editors. Oxford Textbook of Psychiatry. $2^{\text {nd }}$ ed. Oxford; Oxford University Press, 1989, 774-5.

6. Illingworth R S. The development of the infant and young child. London; Churchill Livingstone, 1975.

7. Elysee T M, Saigal S, Wolke D, Lambert M et al. Behavioural problems in children who weighed $1000 \mathrm{~g}$ or less at birth in four countries. The Lancet 2001; 357:1641-3. 
